\title{
Water sources for woody shrubs on hillslopes; an investigation using isotopic and sapflow methods
}

\author{
Bruce D. Dudley ${ }^{1}$, Hannu Marttila ${ }^{2}$, Scott L. Graham ${ }^{1}$, Ryan Evison ${ }^{3}$, M.S. Srinivasan ${ }^{1}$ \\ ${ }^{1}$ National Institute of Water and Atmospheric Research (NIWA), Christchurch, New Zealand \\ ${ }^{2}$ Department of Process and Environmental Engineering, Water Resources and Environmental \\ Engineering Research Unit, University of Oulu, Finland \\ ${ }^{3}$ National Institute of Water and Atmospheric Research (NIWA), Wellington, New Zealand \\ *corresponding author: bruce.dudley@niwa.co.nz
}

\section{Abstract}

Shrub encroachment into grasslands is a globally occurring process, but resulting changes to catchment water flows and stores are not yet well understood. We examined seasonal patterns of water sources for regenerating woody shrubs in seasonally dry montane farmland. We compared stable isotope ratios of shrub stem water to soil water pools at various depths within the vadose zone, groundwater, and stream water. We compared the results of these water source analysis with riparian plant water uptake measured using sap flux sensors, and some potential drivers of sap flow rates (soil moisture and meteorological data). The stable isotope data indicated that the shrubs derived the majority of their water from shallow soil (top $10 \mathrm{~cm}$ ), during the summer growing season. Sapflow measurements provided support for the isotope results, as riparian shrubs showed a springtime peak in water use and reduced sapflow rates during late summer driven by intermittent drying of shallow soil layers. Analysis of groundwater and streamwater indicated that these water sources were isotopically separated from plant and shallow soil water, and fed primarily by precipitation falling during winter months. Our results indicate that transpiration of groundwater that may otherwise have fed streamflow is likely to be minor during early stages of shrub regeneration. This is important 
because shrubs are costly to remove and also have measureable benefits for sediment retention and soil fertility on montane farms.

Key words: transpiration, stable isotopes, low flow, sap flow, headwater/first order catchment

\section{Introduction:}

Conventional hydrology conceptualizes the existence of a continuum of water movement, where new water replaces old or pre-existing water within subsurface zones (Buttle, 1998). However, spatial and temporal variations in the amount of water used by terrestrial vegetation influence the state and availability of water resources within a catchment, and thus the magnitude and timing of flows to surface waters and groundwater. This process is further complicated when plants change their water sources over time (Eggemeyer et al., 2009; McCole \& Stern, 2007), or in space (Dudley, Hughes, \& Ostertag, 2014; Gries et al., 2003) within a catchment. Advances in the application of stable isotopes in hydrological and ecological studies have allowed in-depth studies of strategies for plant water uptake from various available surface and sub-surface pools. Based on ecohydrological studies in Mediterranean and sub-humid catchments, respectively, Brooks, Barnard, Coulombe, and McDonnell (2010) and Goldsmith et al. (2012) proposed the existence of two subsurface pools, one supporting transpiration and the other groundwater and streamflow. Their data suggest that mobile soil water and flow through preferential soil pathways supply groundwater and streamflow, while a less mobile soil matrix pool that is subject to greater evaporation supplies summer transpiration. Later, McDonnell (2014) and Evaristo, Jasechko, and McDonnell (2015) used this as the basis for a "two water worlds" hypothesis and provided further evidence that the precipitation which supplies groundwater recharge and streamflow is commonly different from the water that supplies parts of soil water recharge and plant transpiration. However, those authors also noted that the degree to which this ecohydrological separation holds true varies between biomes. At catchment scale, it is likely that ecohydrological separation often 
varies spatially (e.g., between hillslope and riparian areas) (Dudley et al., 2014). Furthermore, (Marttila, Dudley, Graham, \& Srinivasan, 2017 - In review) show that even vegetation situated in riparian areas and in-stream varies its water use between readily available streamwater, soil water, and groundwater over time. A mechanistic understanding of the processes that determine vegetation water sources is thus vital for quantification of vegetation effects on catchment water yield.

Shrub encroachment can impact water balance in a catchment, particularly through increased interception and increased rooting depth. Notably, streamflow can generally be expected to decline as a result of woody plant encroachment in landscapes that are dominated by subsurface flow regimes (Huxman et al., 2005). Rooting depth determines the soil volume from which plants can potentially draw water (Zhang, Dawes, \& Walker, 2001), and changes in rooting depth and density can alter access to various sub-surface water stores with differing connectivity to surface water. In particular, increases in deep-rooting plants within catchments, which result in increased use of groundwater sources, have been shown to reduce flow to surface water bodies, especially when such deep-rooting plants become established in riparian areas (Dahm et al., 2002; Le Maitre, Versfeld, \& Chapman, 2000). However, the possibility also exists that much of the water used by encroaching shrubs is derived from shallow soil layers, which may be poorly connected to waters that feed groundwater and streamflow (e.g., Brooks et al. (2010)).

Stable isotopes of hydrogen and oxygen are useful indicators of water movements through catchments and of the hydrological cycle in general (Gat 1996). While dual stable isotope approaches have applications for assessing the degree to which woody vegetation affects catchment water flows, only a handful of studies of this type have been undertaken for temperate grasslands. Within these studies, there is evidence of a range of controls (such as 
bedrock characteristics, climate, and plant traits) on water sources of woody vegetation (Eggemeyer et al., 2009; Kukowski, Schwinning, \& Schwartz, 2013; McCole \& Stern, 2007). Lang's Gully is typical of the Canterbury foothills landscape, where low productivity grasslands are spread across the foothills of montane areas, upslope of fertile agricultural plains. Shrub-encroachment is common feature of these low-producing pasture catchments (Holdaway, Easdale, Mason, \& Carswell, 2014), however water sources for these encroaching shrubs have not been investigated. Therefore in this study we examined the seasonal isotopic signatures of precipitation, groundwater, streamflow, surface soil water, and stem water in an agricultural catchment re-colonized by the native shrub matagouri (Discaria toumatou Raoul, family Rhamnaceae). Recent research has shown ambiguities in vegetation water source studies that use dual isotope analysis, highlighted by comparison to those that rely on single isotope mixing models (e.g., (Bowling, Schulze, \& Hall, 2017). Because of this, we utilized sap flux, soil moisture, and meteorological measurements, in conjunction with a hydrogen and oxygen dual stable isotope approach to determine water sources for matagouri. Our objectives were to test whether the 'two water worlds hypothesis' holds for this species, and whether this was equally true from ridge to riparian zones. Our hypotheses for this work were that: 1) matagouri intercepts and transpires water that would otherwise have recharged groundwater and/or resulted in streamflow; and 2) use of groundwater by matagouri is greater in areas where the watertable is closer to the surface, such as near-stream riparian areas, than in areas where such sources are not readily accessible (e.g., far-stream back-slope and head-slope areas).

\section{Materials and methods:}

\subsection{Study system}

The study was conducted in Lang's Gully, a small $\left(0.7 \mathrm{~km}^{2}\right)$ headwater catchment in the foothills of the Southern Alps in North Canterbury, South Island, New Zealand (4256'19.35"S, $172^{\circ} 25^{\prime} 8.26$ "E; elevation range 500 to $750 \mathrm{~m}$ ) (Figure 1 ). The geology in the catchment is 
primarily greywacke and argillite sedimentary bedrock (Suggate, Stevens, \& Te Punga, 1978). The soils are shallow gravelly silt loams derived from the underlying greywacke, which tend to have greater sand and gravel content and decreasing clay content with greater depth, and on spurs, relative to foot slopes (McMillan and Srinivasan 2015). Mean annual precipitation (1972-2014) is $943 \mathrm{~mm} \mathrm{yr}^{-1}$ (range 500-1100 mm $\mathrm{yr}^{-1}$ ) and potential evapotranspiration (Penman method) ranges from 432 to $958 \mathrm{~mm} \mathrm{yr}^{-1}$. Mean annual temperature at the Lang's Gully climate station from January 1,2011 to January 1,2016 was $9.4^{\circ} \mathrm{C}\left(\max 31.7^{\circ} \mathrm{C}\right.$, min 7. $5^{\circ} \mathrm{C}$ ). Streamflow leaving the Lang's Gully catchment averages $3.3 \mathrm{~L} \mathrm{~s}^{-1}$, with extended hot dry periods in the summer leading to both north and south branches running dry (McMillan \& Srinivasan, 2015).

The catchment has been farmed since the early $20^{\text {th }}$ century and is currently used primarily for low-intensity, grazing-based, pastoral (sheep and beef) farming. In the 1960s and 1970s the practice of burning vegetation in Canterbury's foothills was curtailed to reduce erosion, leading to recovery of matagouri-dominated shrubland (Figure 2 and Figure A1). This recovery of matagouri-dominated shrubland has resulted in increased biodiversity in these farmland areas (Whitehead, Byrom, Clayton, \& Pech, 2014). Those stands of matagouri originating post 1990 also provide significant carbon sequestration benefits (Holdaway et al. 2014). Matagouri is a thorny, actinorhizal nitrogen-fixing shrub indigenous to New Zealand, and common throughout the eastern South Island and lower North Island. It is winter deciduous, slow growing and longlived; stands with size structures similar to those measured in this study have measured ages of between 10 and 100 years (Bellingham, 1998). The North Waipara River catchment, in which Lang's Gully is located, supports forestry, sheep, beef, and deer farming in the upper hill country, while viticulture and sheep and beef farming dominate the lower reaches. Water use is a contentious issue throughout the catchment due to competing water users, combined with the scarce water supply during hot and dry summer months. Flow regimes in the lowland New 
Zealand rivers are of particular concern, as they influence the abundance of fish species (Crow, Booker, \& Snelder, 2013), and the availability of water for irrigation. Therefore New Zealand regional authorities frequently place conditions on irrigation permits that include sufficient flow in adjacent rivers.

\section{Figure 1 near here}

\section{Figure 2 near here}

\subsection{Climate, groundwater, and soil measurements}

Meteorological data were collected at a weather station located at a central site within the catchment (Figure 1). They included wind speed and direction, air temperature, barometric pressure, and relative humidity data collected with a Vaisala WXT520 weather transmitter. Solar radiation was measured with a LiCOR LI200 pyranometer, while rainfall was measured with an OTA OSK15180T $0.2 \mathrm{~mm}$ resolution tipping bucket gauge. All weather data were collected at 5-min intervals. Soil moisture and depth to the unconfined watertable were monitored at 10 instrument stations on the north-facing slope of the catchment, as described elsewhere (McMillan \& Srinivasan, 2015). In brief, the stations were set up in two rows of five sites, with each site containing two Acclima TDT soil moisture sensor sensors, at 30 and 60 $\mathrm{cm}$, and a Solinst level-logger to measure water level in an adjacent $1.5 \mathrm{~m}$ well. Samples for water retention curve $(\mathrm{pF})$ and hydraulic conductivity $(\mathrm{K})$ calculations were taken in sharpened steel cylinders (diameter $4 \mathrm{~cm}$, volume $\left.50 \mathrm{~cm}^{3}\right)$ at four locations and from three depths $(0-5$, 30-35, and 60-65 cm) across the Lang's Gully catchment. At the Geotechnical Laboratory, University of Oulu, Finland, $\mathrm{pF}$ curves were determined using a ceramic pressure plate 
apparatus under pressures from 0.0125 to 10 bar and hydraulic conductivity $(\mathrm{K})$ using a constant head permeameter.

\subsection{Isotope sampling}

To examine differences in water sources between landscape positions in the catchment, we placed seven plots between ridgeline (far-stream and greater depth to the watertable) and stream (near-stream and shallow depth to the watertable) on the north-facing (southern) slope of Lang's Gully. Each plot was separated by around $90 \mathrm{~m}$ from its closest neighbor (Figure 1). We placed a fixed marker at the center point of each plot, and conducted all isotope sampling haphazardly within $7.5 \mathrm{~m}$ of that point. We used hydrogen and oxygen stable isotope ratios ( $\delta^{2} \mathrm{H}$ and $\delta^{18} \mathrm{O}$ values) to evaluate water sources for matagouri, and seasonality of soil moisture resupply by precipitation. Streamwater samples were taken at the sites of the two flow monitoring stations within the catchment at monthly intervals from August 2014 until March 2016 (Figure 1). Throughout this period, samples were collected during baseflow conditions. We collected soil samples for water extraction from $10 \mathrm{~cm}, 30 \mathrm{~cm}$ and $60 \mathrm{~cm}$ depth, where soil was present, in all seven Lang's Gully plots at monthly intervals from March 2015 to March 2016. All soil water isotope samples were collected in duplicate, and the moisture content of duplicates was analyzed by drying at $105^{\circ} \mathrm{C}$ to constant weight. Samples from March, April, and May 2015 were also analyzed for organic matter content by combustion at $500^{\circ} \mathrm{C}$. We collected three fully suberized stem segments, approximately $4 \mathrm{~cm}$ in length, from one matagouri plant selected haphazardly from within each plot, in each month. The diameter of each sample shrub was recorded at $100 \mathrm{~mm}$ above ground level, to avoid any roots or buttressing. Stem segments and soil samples were immediately placed in plastic vials with screw-top lids and sealed with Parafilm (Bemis Flexible Packaging, Neenah, Wisconsin, USA), kept on ice during transport, and frozen during storage and shipping. Stem and soil water extraction and $\delta^{2} \mathrm{H}$ and $\delta^{18} \mathrm{O}$ analysis of subsequent water samples were performed at the Stable 
Isotope Ratio Facility for Environmental Research (SIRFER), University of Utah, Salt Lake City, Utah, USA. Water extraction was performed following West, Patrickson, and Ehleringer (2006). The $\delta^{2} \mathrm{H}$ and $\delta^{18} \mathrm{O}$ values for soil and stem samples were measured by isotope ratio infrared spectroscopy (IRIS) on a wavelength-scanned, cavity ring-down spectrometer (WSCRDS) model L1102-i water analyzer (Picarro, Sunnyvale, California, USA). Samples were analyzed against three laboratory reference materials calibrated to Vienna Standard Mean Ocean Water (VSMOW). The $\delta^{2} \mathrm{H}$ and $\delta^{18} \mathrm{O}$ values for precipitation, streamwater, and groundwater were analyzed using similar WS-CRDS equipment at the National Institute of Water and Atmospheric Research in Christchurch, New Zealand, using three further isotopic standards calibrated to VSMOW. Isotope values for soil and plant water and for streamwater collected within Lang's Gully were compared with isotope values in groundwater collected at the outflow point of Lang's Gully, and in daily precipitation collected within the greater catchment as part of a concurrent study examining riparian vegetation effects on river flows (Marttila et al., 2017 - In review). Sampling locations for these data are indicated in Figure 1.

\subsection{Sapflow measurement}

The stand-level sapwood area and stem density of matagouri shrubs were determined by measuring the diameter at $10 \mathrm{~cm}$ above ground level (above any roots or buttressing) for all stems within each $7.5 \mathrm{~m}$ radius at five of the plots (M1-M5) within Lang's Gully. Shrubs used to examine controls of sapflow were selected in the central, riparian site near the weather station where groundwater was likely to be accessible to deep-rooted species. Eight matagouri shrubs with varying basal diameter were selected, to represent the size distribution of the stand throughout the catchment, according to Čermák, Kučera, and Nadezhdina (2004). The diameter of the eight selected plants ranged from 22 to $92 \mathrm{~mm}$. Sap fluxes were measured using the ‘compensation' heat pulse velocity (HPV) method (Green \& Clothier, 1988). The HPV method is based on the method of Swanson and Whitfield (1981), and comprises a set of probes and 
associated electronics (Tranzflo NZ Ltd, Palmerston North, New Zealand) connected to a data logger (Campbell Scientific, CR1000). Temperature pulses to shrubs were spaced at 30-min intervals, and temperature data from thermocouple pairs were subsequently collected at 1-s intervals. Conversion of heat pulse and stem size data to sapflow rates required data on: 1) Bark depth for the sample shrubs; and 2) wood, air, and water fractions of sapwood. Because sapflow has not previously been studied in this shrub species, we measured these parameters in sample populations of stems, with diameter ranges that approximated the range of stem sizes on which we calculated sapflow. These data are presented in Table A1. Over the size range of stems used in this study, there was a linear relationship between stem size and bark depth. This relationship was used to estimate bark depth in the stems used in sapflow analysis. We found no dependence of wood, air, and water fractions of sapwood on stem size, so the sample means for these parameters were used in sap flux calculations. We monitored sap flux rates every half hour from December 6, 2014 to May 11, 2016. Sensors were checked and repositioned on stems approximately every three months to reduce the effects of wounding on sap flux rate estimates (Green, Clothier, \& Jardine, 2003). Because not all sap flux sensor installations delivered adequate data quality at all time points over the duration of the study, we calculated mean sapflow for all the sample shrubs for which we had good data, averaged for each 30-min time interval. We used these mean values in subsequent plotting (i.e. Fig. 6), and we used nonaveraged data from individual shrubs in analysis of transpiration controls.

\subsection{Data analysis}

\subsubsection{Calculation of precipitation offsets}

Precipitation offsets of water samples from within the catchment (soil water, streamwater, groundwater, and stem water) were calculated by their deviation from the local meteoric water line established in (Marttila et al., 2017 - In review) according to Landwehr and Coplen (2006), who referred to his method as line-conditioned excess (lc): 
$l c=\left[\delta^{2} H-a \delta^{18} O-b\right] / S$

where $a$ and $b$ are the slope and y intercept of the local meteoric water line, respectively, calculated from weighted values of precipitation collected daily at each study site, and $\mathrm{S}$ is one standard deviation of the measurement uncertainty for both $\delta^{2} \mathrm{H}$ and $\delta^{18} \mathrm{O}$.

Because stem water isotope values collected over the course of a year are likely to be biased towards periods when transpiration is low (Evaristo et al., 2015), we derived weighted lc values for stem water at each site, using monthly sapflow (summed for the eight sample plants) as a proportion of summed annual sapflow, to weight isotope values:

$l c($ weighted $)=\frac{\sum_{i=1}^{n} l c(\text { weighted })_{(i)} T_{i}}{\sum_{i=1}^{n} T_{i}}$

where $l c(\text { weighted })_{(i)}$ is the isotopic composition of stem water during sampling month $\mathrm{i}$ and $\mathrm{T}_{\mathrm{i}}$ is the sapflow volume from matagouri in our experimental plot during month $\mathrm{i}$.

\subsubsection{Calculation of source water isotope values}

Precipitation in the study area (and in many temperate areas) shows a pronounced annual cycle of isotope values, which can be used to shed light on the timing of precipitation supplying various stores of water in the catchment (Gat, 1996). We calculated the isotopic composition of the precipitation from which soil water and matagouri stem water originated, for comparison with the precipitation sources supplying groundwater and streamwater, characterized for this catchment by (Marttila et al., 2017 - In review). We calculated the y coordinate $\left(\delta^{2} \mathrm{H}\right.$ value) and $\mathrm{x}$ coordinate $\left(\delta^{18} \mathrm{O}\right.$ value) of the intersection points in isotope space of evaporation lines with local meteoric water lines (LMWL), to give the isotope values of these precipitation 
sources using a method similar to Javaux, Rothfuss, Vanderborght, Vereecken, and Brüggemann (2016):

$\delta_{18} O$ intercept $=\frac{(b-n+z)}{m-a}$

$\delta_{2} \mathrm{H}$ intercept $=\left(a \delta_{18} \mathrm{O}\right.$ intercept $)+b$

where $a, b, m$, and $n$, are the slope of the LMWL, the LMWL intercept, the evaporation line slope, and the evaporation line intercept, respectively, and $\mathrm{z}$ is the distance in $\delta^{2} \mathrm{H}$ space of individual sample $\delta^{2} \mathrm{H}$ values above or below the evaporation line, calculated as:

$z=\delta^{2} H_{\text {sample }}-\left(m \delta^{18} O_{\text {sample }}+n\right)$

where, as above, $\mathrm{m}$ is the slope of the evaporation line and $\mathrm{n}$ is the intercept of the evaporation line. We note that equation 3 therefore relies on the assumption that evaporation line slopes for individual samples are equal to $m$.

\subsubsection{Statistical analyses}

To compare isotopic indices (i.e., lc-excess and $\delta^{18} \mathrm{O}$-intercept) between water sources within the catchment, we first tested whether or not our data met the assumption for ANOVA of equal group variances, using Levene's test. In comparisons of both precipitation offset and oxygen intercept, we found significantly different variances between groups (water sources), so we tested for differences in group means using Welch's ANOVA (Welch, 1951), which is more robust to variance heterogeneity. Where we found significant differences due to water source using Welch's ANOVA, we tested for differences between pairs of water sources using posthoc Games-Howell tests (Games \& Howell, 1976). We conducted analyses on data from within the growing season of matagouri (October 1 to May 31), as well as the full dataset. We tested for effects of matagouri stem diameter (as a potential surrogate for root depth and groundwater 
access) on isotopic indices of stem water with linear models. We also tested for an effect of hillslope position on isotopic indices of stem water, using Welch's ANOVA, treating sampling site as the grouping variable.

We tested controls on sap flux in matagouri stems for significance using linear mixed-effects modeling. Solar radiation, VPD, and soil moisture at 30 and $60 \mathrm{~cm}$ soil depth were all investigated as drivers of sap flux. In order to account for repeated measurements on the same stems, individual measurements were assigned as a random factor. A maximal model, including all drivers, was compared against a model with drivers dropped. Minimization of Akaike's Information Criterion was used as the basis for model selection. Analyses were conducted using the 'nlme' (Pinheiro, Bates, DebRoy, Sarkar, \& R Core Team, 2016), 'car' (Fox \& Weisberg, 2011), and 'userfriendlyscience' (Peters, 2016) packages of R v3.3.3 (R Core Team, 2017).

\section{Results}

Welch's ANOVA analysis of lc-excess between water sources indicated strong hydrological separation of water in matagouri stems from streamwater and groundwater in this catchment (corrected ANOVA F $6,62.41=154.44, \mathrm{p}<0.001$ ) (Figure 3, Figure 4A for Games-Howell test results). There were also significant differences in the annual mean lc-excess of water in matagouri stems from that in soil, particularly deeper $(30 \mathrm{~cm}$ and $60 \mathrm{~cm})$ soil layers. This was the case whether or not stem lc-excess values were weighted by monthly transpiration rate. However, there was overlap between the lc-excess ranges of matagouri, and $10 \mathrm{~cm}, 30 \mathrm{~cm}$ and $60 \mathrm{~cm}$ soil layers. There were no differences $(\alpha>0.05$, Games-Howell tests) between results when we used the full year dataset and when we used stem water isotope results weighted using sapflow data. We did not detect differences in lc-excess of water in matagouri stems due to position between ridgeline and river. We were also unable to detect differences in lc-excess of 
water in matagouri stems due to differing basal diameter. We were unable to detect differences between the mean lc-excess of soil water at $10 \mathrm{~cm}, 30 \mathrm{~cm}$, and $60 \mathrm{~cm}$. Variability in lc-excess was very high in stem water (whole year) and shallow soil layers, and less in deeper $(30 \mathrm{~cm}$ and $60 \mathrm{~cm}$ ) soil layers, streamwater, and groundwater, respectively (Levene's test for unequal variances $\left.\mathrm{F}_{6,359}=14.2, \mathrm{p}<0.001\right)$.

\section{Figure 3 near here}

\section{Figure 4 near here}

Differences in variability in lc-excess with soil depth could be explained by $\delta^{18} \mathrm{O}$-intercept results for soils (Figure 5). Isotope values of precipitation are highly variable at this site, showing peaks in summer months and low values in cool winter months (Figure 5A). This annual variation was expressed to varying degrees in different soil layers, and in stem water, groundwater, and streamwater (Levene's test for unequal variances $F_{5,347}=16.8, p<0.001$ ). The greatest variances were in calculated $\delta^{18} \mathrm{O}$-intercept values were observed in shallow soil layers, followed by deeper (30 and $60 \mathrm{~cm}$ ) soil layers, stem water (whole year), streamwater, and groundwater (Figures 4 and 5). Mean $\delta^{18} \mathrm{O}$-intercept values were significantly different between pools of water within the catchment (corrected ANOVA: $F_{5}, 120.84=211.31, \mathrm{p}<0.001$ ) (Figure 4A for Games-Howell test results, Figure 5). Stem water, groundwater, and streamwater had calculated $\delta^{18} \mathrm{O}$-intercept values similar to the annual average for the site, while soil at increasing depths had progressively lower calculated source water $\delta^{18} \mathrm{O}$ values characteristic of winter rainfall. Over all sites, we detected a marginal effect of matagouri stem size on stem water $\delta^{18} \mathrm{O}$-intercept values (stem diameter at $10 \mathrm{~cm} ; \mathrm{F}_{1,71}=3.09, \mathrm{p}=0.08$ ), which would suggest that larger plants (with presumably greater potential rooting depth) have a tendency to access water with a lower source $\delta^{18} \mathrm{O}$ value (i.e., derived more from winter precipitation) than small plants.

\section{Figure 5 near here.}


Sapflow was almost undetectable during the coldest months, when leaves were absent (between late May and September), and highest in late spring, when it peaked at $0.27 \mathrm{~L} \mathrm{~h}^{-1}$ in the largest of the eight sample plants. Over the duration of the study, the maximum 24-hour average of the eight sample plants was $0.040 \mathrm{~L} \mathrm{~h}^{-1}\left(0.98 \mathrm{~L} \mathrm{day}^{-1}\right.$; Figure 6). Not surprisingly, our model results suggested that sapflow was largely controlled by daily radiation and VPD (Table 1). The best fit model included soil moisture at both $30 \mathrm{~cm}$ and $60 \mathrm{~cm}$ depth, but these moisture data were strongly correlated and there was little difference between models using both or either of the moisture datasets as predictors. These data suggest that, in addition to radiation and VPD controls, sapflow at this stream-side site is limited by soil moisture at relatively shallow depth below the ground surface. Both soil organic content (data not shown) and soil water retention (Figure A3) were highest in shallow $(<10 \mathrm{~cm})$ soils.

\section{Figure 6 near here.}

\section{Table 1 near here.}

\section{Discussion}

Our first hypothesis, that matagouri transpires water that would otherwise have contributed to groundwater and streamwater, was not supported by the results of lc-excess comparisons between soil water pools. Groundwater and streamwater showed very low lc-excess values that were not similar to those of matagouri stem water at any site. Our analysis suggested that matagouri plants predominantly transpired water sources from which there had been considerable evaporation ; lc-excess of stem water was most similar to that of soil water collected from $10 \mathrm{~cm}$ below ground level. However, the means of these two pools were significantly different, suggesting that the majority of water used by plants was taken from depths shallower than $10 \mathrm{~cm}$ that had been subject to proportionally greater evaporation. . Groundwater access, or the tendency of matagouri to take up and transpire groundwater, was not discernibly greater at sites nearer the stream, where groundwater is presumably shallower. 
We were also unable to show using lc-excess values that larger plants (with presumably greater potential rooting depth) have a tendency to access deeper water with a lower lc-excess than small plants.

The reliance of matagouri on shallow soil water, rather than deeper groundwater that feeds summer streamflow in this catchment (McMillan \& Srinivasan, 2015), was supported by linear model analysis of sapflow data from a streamside site. This analysis showed a significant reduction in sapflow when shallow soil layers became dry in mid-late summer (Figure 6). While our sapflow analysis does not rule out groundwater use by matagouri, it agrees with isotope results in that it indicates that matagouri plants did not take up sufficient groundwater to meet evaporative demand when shallow soil layers were very dry (Miyazawa et al., 2016). However, shallow $(10 \mathrm{~cm})$ soil layers were most commonly drier during summer months than deeper $(30$ and $60 \mathrm{~cm})$ soil layers. A potential reason suggested for preferential uptake of water from relatively drier shallow soil over deeper soil water sources is that shallow soil layers provide a greater source of nutrients (Goldsmith et al., 2012), dictating preferential efforts in water uptake by shallow roots. This mechanism seems plausible during summer months in the study catchment, where analysis of soil structure showed that shallower $(10 \mathrm{~cm})$ soil layers had high water-holding capacity (Figure A3). Typically, the organic matter content of shallow soil layers substantially exceeds that of deeper layers, and periodic wetting events that wet only shallow surface soil have been shown to contribute substantially to nutrient fluxes in dryland ecosystems (Austin et al., 2004). However, we note that matagouri is an actinorhizal N-fixer, and so may increase both N (Hughes \& Denslow, 2005; Vitousek, Walker, Whiteaker, MuellerDombois, \& Matson, 1987) and potentially P (Allison, Nielsen, \& Hughes, 2006; Houlton, Wang, Vitousek, \& Field, 2008) availability in the relatively infertile soils at the study site. In addition, our sapflow measurements showed very low water use compared with similar sized 
shrubs from other dry systems (Allen \& Grime, 1995; Xia, Kang, Li, Zhang, \& Zhou, 2008), which suggests that water use by this species at a catchment scale may be relatively low.

Our second hypothesis, that use of groundwater/streamwater by matagouri is greater in riparian areas where the groundwater is shallower (rather than upper hillslopes), was also not supported by the results. Indeed, we found little to suggest that matagouri at different locations on the hillslope used water from differing soil depths, as lc-excess of stem water was most similar to that of soil water collected from $10 \mathrm{~cm}$ below ground level and linear models did not provide evidence to suggest that this varied with position on the hillslope. This is in contrast to findings in some previous studies of invasive phreatophytes in more arid biomes (e.g. (Dudley et al., 2014; Gries et al., 2003). It may result from the relatively consistent soil profile from stream to ridgeline on the hillslope in the present study. There was little change in soil moisture profile or soil depth between the study sites that might have driven differing depths of soil water sources for matagouri.

Analysis of annual patterns of precipitation source $\delta^{18} \mathrm{O}$ values for $10 \mathrm{~cm}$ soil samples showed a pronounced annual cycle, similar to the annual cycle of $\delta^{18} \mathrm{O}$ values measured in precipitation. This annual cycle of soil water was less apparent at greater $(30$ and $60 \mathrm{~cm})$ soil depths. The running average $\delta^{18} \mathrm{O}$ value of source precipitation for matagouri stem water were substantially less variable than that of shallow soils, remaining at around $-11 \%$. This value is close to precipitation values between autumn and early spring, and soil water source precipitation values calculated for shallow $(10 \mathrm{~cm})$ soils collected during summer. It is quite possible that stem water values from samples taken during winter months are also influenced by summer uptake by roots; sapflow analysis showed that transpiration decreased to near zero as leaves were lost in late May-June and increased again at leaf-burst in September-October. These results are largely supportive of the "two water worlds" hypothesis (Evaristo et al., 2015; 
McDonnell, 2014), in that they suggest that during summer soil-bound water is replenished only at shallow depths. In summer months, shallow soil water is likely to be largely transpired by grasses and matagouri. Winter precipitation appears to replenish water bound in both shallow and deeper soil. These results are in general agreement with lysimeter and eddy covariance studies conducted in the Canterbury region of New Zealand by Duncan, Srinivasan, and McMillan (2016) and Graham, Srinivasan, Faulkner, and Carrick (2017, in review). Those studies showed the majority of groundwater recharge takes place after a succession of winter rainfall events, and that the majority of summer rainfall is evaporated or transpired during summer months. This provides an example of how examining seasonal variability in meteoric water line offset and in the precipitation from which stem water originates can be useful for tracing movements between catchment water pools.

\section{Conclusions}

Shrub encroachment into grassland is a globally occurring process with the potential to alter hydrological regimes, e.g. by lowering streamflow in landscapes dominated by subsurface flow regimes. However, our research in a headwater catchment where summer flow is predominantly groundwater-fed indicates that hydrological impacts of shrub (matagouri) transpiration in headwater catchments are likely to be confined to competitive interactions with other shallow-rooted plant species. We would not expect these impacts to extend to larger, downstream catchments. Moreover, we saw little evidence to suggest that landscape position altered groundwater uptake. Hence, we cannot suggest priority areas of the landscape (i.e. riparian zones) where targeted removal of regenerating shrubs would have a disproportionate effect on catchment hydrology. Furthermore, water use by matagouri was low during early stages of regeneration. Therefore, we suggest that decisions regarding control of matagouri encroachment should consider local-scale light, nutrient and hydrological interactions with other plant species, together with their larger scale interception and sediment retention 
characteristics. Matagouri, an actinorhizal $\mathrm{N}$-fixer, may increase both $\mathrm{N}$ and potentially $\mathrm{P}$ in the relatively infertile montane soils studied. Investigations of the nutrient deposition characteristics of this species, together with investigations of light reductions beneath matagouri, may further inform management decisions.

\section{Acknowledgements}

We thank land owners Dugald and Mandy Rutherford for their kindness and scientific curiosity. Photo credits for figure 2: Ken Rutherford (left panel); Dugald Rutherford (right panel). We thank Pieter Havelaar, Jeremy Rutherford, Marty Flanagan, Hilary McMillan, and Natalie Faulkner for their efforts in the field and laboratory in often trying conditions. Steve Green constructed the sap flux equipment and assisted with analysis. Peter Hairsine advised on manuscript style and structure. This research was funded by the NZ Ministry of Business, Innovation and Employment through WaterScape programme (contract C01X1006). 


\section{References}

Allen, S. J., \& Grime, V. L. (1995). Measurements of transpiration from savannah shrubs using sap flow gauges. Agricultural and Forest Meteorology, 75(1), 23-41. doi:http://dx.doi.org/10.1016/0168-1923(94)02201-T

Allison, S. D., Nielsen, C., \& Hughes, R. F. (2006). Elevated enzyme activities in soils under the invasive nitrogen-fixing tree Falcataria moluccana. Soil Biology and Biochemistry, 38(7), 1537-1544. doi:10.1016/j.soilbio.2005.11.008

Austin, A. T., Yahdjian, L., Stark, J. M., Belnap, J., Porporato, A., Norton, U., . . Schaeffer, S. M. (2004). Water pulses and biogeochemical cycles in arid and semiarid ecosystems. Oecologia, 141(2), 221-235. doi:10.1007/s00442-004-1519-1

Bellingham, P. J. (1998). Shrub succession and invasibility in a New Zealand montane grassland. Australian Journal of Ecology, 23(6), 562-573. doi:10.1111/j.14429993.1998.tb00766.x

Bowling, D. R., Schulze, E. S., \& Hall, S. J. (2017). Revisiting streamside trees that do not use stream water: can the two water worlds hypothesis and snowpack isotopic effects explain a missing water source? Ecohydrology, 10(1), e1771. doi: 10.1002/eco.1771

Brooks, J. R., Barnard, H. R., Coulombe, R., \& McDonnell, J. J. (2010). Ecohydrologic separation of water between trees and streams in a Mediterranean climate. Nature Geoscience, 3(2), 100-104.

Buttle, J. M. (1998). Fundamentals of small catchment hydrology (Vol. 839): Elsevier: Amsterdam.

Čermák, J., Kučera, J., \& Nadezhdina, N. (2004). Sap flow measurements with some thermodynamic methods, flow integration within trees and scaling up from sample trees to entire forest stands. Trees, 18(5), 529-546.

Crow, S. K., Booker, D. J., \& Snelder, T. H. (2013). Contrasting influence of flow regime on freshwater fishes displaying diadromous and nondiadromous life histories. Ecology of Freshwater Fish, 22(1), 82-94.

Dahm, C. N., Cleverly, J. R., Coonrod, J. E. A., Thibault, J. R., McDonnell, D. E., \& Gilroy, D. F. (2002). Evapotranspiration at the land/water interface in a semi-arid drainage basin. Freshwater Biology, 47(4), 831-843.

Dudley, B. D., Hughes, R. F., \& Ostertag, R. (2014). Groundwater availability mediates the ecosystem effects of an invasion of Prosopis pallida. Ecological Applications, 24(8), 1954-1971. doi:10.1890/13-1262.1

Duncan, M. J., Srinivasan, M. S., \& McMillan, H. (2016). Field measurement of groundwater recharge under irrigation in Canterbury, New Zealand, using drainage lysimeters. Agricultural Water Management, 166, 17-32. doi:http://dx.doi.org/10.1016/j.agwat.2015.12.002

Eggemeyer, K. D., Awada, T., Harvey, F. E., Wedin, D. A., Zhou, X., \& Zanner, C. W. (2009). Seasonal changes in depth of water uptake for encroaching trees Juniperus virginiana and Pinus ponderosa and two dominant $\mathrm{C}_{4}$ grasses in a semiarid grassland. Papers in Natural Resources, 202.

Evaristo, J., Jasechko, S., \& McDonnell, J. J. (2015). Global separation of plant transpiration from groundwater and streamflow. Nature, 525(7567), p 91.

Fox, J., \& Weisberg, S. (2011). An R Companion to Applied Regression, Second Edition. Thousand Oaks, CA Sage.

Games, P. A., \& Howell, J. F. (1976). Pairwise multiple comparison procedures with unequal n's and/or variances: a Monte Carlo study. Journal of Educational Statistics, 1(2), 113-125. 
Gat, J. R. (1996). Oxygen and hydrogen isotopes in the hydrologic cycle. Annual Review of Earth and Planetary Sciences, 24(1), 225-262.

Goldsmith, G. R., Muñoz-Villers, L. E., Holwerda, F., McDonnell, J. J., Asbjornsen, H., \& Dawson, T. E. (2012). Stable isotopes reveal linkages among ecohydrological processes in a seasonally dry tropical montane cloud forest. Ecohydrology, 5(6), 779790.

Graham, S. L., Srinivasan, M. S., Faulkner, N. and Carrick, S. Soil hydraulic modelling outcomes with four parameterization methods: comparing soil description and inverse estimation approaches. Vadose Zone Journal. In review.

Green, S. R., \& Clothier, B. E. (1988). Water use of kiwifruit vines and apple trees by the heat-pulse technique. Journal of Experimental Botany, 39(1), 115-123.

Green, S. R., Clothier, B. E., \& Jardine, B. (2003). Theory and practical application of heat pulse to measure sap flow. Agronomy Journal, 95(6), 1371-1379.

Gries, D., Zeng, F., Foetzki, A., Arndt, S. K., Bruelheide, H., Thomas, F. M., . . Runge, M. (2003). Growth and water relations of Tamarix ramosissima and Populus euphratica on Taklamakan desert dunes in relation to depth to a permanent water table. Plant Cell and Environment, 26(5), 725-736.

Holdaway, R., Easdale, T., Mason, N., \& Carswell, F. (2014). LUCAS natural forest carbon analysis. Prepared for the Ministry for the Environment by Landcare Research. Ministry for the Environment, Wellington.

Houlton, B. Z., Wang, Y.-P., Vitousek, P. M., \& Field, C. B. (2008). A unifying framework for dinitrogen fixation in the terrestrial biosphere. Nature, 454(7202), 327-330.

Hughes, R. F., \& Denslow, J. S. (2005). Invasion by a $\mathrm{N}_{2}$-fixing tree alters function and structure in wet lowland forests of Hawaii. Ecological Applications, 15(5), 16151628.

Huxman, T. E., Wilcox, B. P., Breshears, D. D., Scott, R. L., Snyder, K. A., Small, E. E., .. . Jackson, R. B. (2005). Ecohydrological implications of woody plant encroachment. Ecology, 86(2), 308-319.

Javaux, M., Rothfuss, Y., Vanderborght, J., Vereecken, H., \& Brüggemann, N. (2016). Isotopic composition of plant water sources. Nature, 536(7617), E1-E3. doi:10.1038/nature18946

Kukowski, K. R., Schwinning, S., \& Schwartz, B. F. (2013). Hydraulic responses to extreme drought conditions in three co-dominant tree species in shallow soil over bedrock. Oecologia, 171(4), 819-830.

Landwehr, J., \& Coplen, T. (2006). Line-conditioned excess: a new method for characterizing stable hydrogen and oxygen isotope ratios in hydrologic systems. Isotopes in environmental studies, 132-135.

Le Maitre, D. C., Versfeld, D. B., \& Chapman, R. A. (2000). The impact of invading alien plants on surface water resources in South Africa: A preliminary assessment. Water SA, 26(3), 397-408.

Marttila, H., Dudley, B. D., Graham, S., \& Srinivasan, M. S. (2017 - In review). Does transpiration from invasive stream side willows dominate low flow conditions? An investigation using hydrometric and isotopic methods in a headwater catchment. Ecohydrology.

McCole, A. A., \& Stern, L. A. (2007). Seasonal water use patterns of Juniperus ashei on the Edwards Plateau, Texas, based on stable isotopes in water. Journal of Hydrology, 342(3), 238-248.

McDonnell, J. J. (2014). The two water worlds hypothesis: Ecohydrological separation of water between streams and trees? Wiley Interdisciplinary Reviews: Water, 1(4), 323329. 
McMillan, H. K., \& Srinivasan, M. S. (2015). Characteristics and controls of variability in soil moisture and groundwater in a headwater catchment. Hydrology and Earth System Sciences, 19(4), 1767-1786.

Miyazawa, Y., Dudley, B. D., Hughes, R. F., Vandemark, J., Cordell, S., Nullet, M. A., . . Giambelluca, T. W. (2016). Non-native tree in a dry coastal area in Hawai'i has high transpiration but restricts water use despite phreatophytic trait. Ecohydrology, 9(7), 1166-1176. doi:10.1002/eco.1715

Peters, G. (2016). userfriendlyscience: Quantitative analysis made accessible (Version R package version 0.5-2 ). Retrieved from http://userfriendlyscience.com

Pinheiro, J., Bates, D., DebRoy, S., Sarkar, D., \& R Core Team. (2016). nlme: Linear and Nonlinear Mixed Effects Models (Version R package version 3.1-128). Retrieved from http://CRAN.R-project.org/package $=$ nlme

R Core Team. (2017). R: A language and environment for statistical computing Vienna, Austria: R Foundation for Statistical Computing. Retrieved from https://www.Rproject.org/

Suggate, R. P., Stevens, G. R., \& Te Punga, M. T. (1978). The Geology of New Zealand (Vol. 2): EC Keating, Govt. Printer.

Swanson, R., \& Whitfield, D. (1981). A numerical analysis of heat pulse velocity theory and practice. Journal of Experimental Botany, 32(1), 221-239.

Vitousek, P. M., Walker, L. R., Whiteaker, L. D., Mueller-Dombois, D., \& Matson, P. A. (1987). Biological invasion by Myrica faya alters ecosystem development in Hawaii. Science, 238(4828), 802-804.

Welch, B. (1951). On the comparison of several mean values: an alternative approach. Biometrika, 38(3/4), 330-336.

Whitehead, A. L., Byrom, A. E., Clayton, R. I., \& Pech, R. P. (2014). Removal of livestock alters native plant and invasive mammal communities in a dry grassland-shrubland ecosystem. Biological Invasions, 16(5), 1105-1118. doi:10.1007/s10530-013-0565-1

West, A. G., Patrickson, S. J., \& Ehleringer, J. R. (2006). Water extraction times for plant and soil materials used in stable isotope analysis. Rapid Communications in Mass Spectrometry, 20(8), 1317-1321.

Xia, G., Kang, S., Li, F., Zhang, J., \& Zhou, Q. (2008). Diurnal and seasonal variations of sap flow of Caragana korshinskii in the arid desert region of north-west China. Hydrological Processes, 22(8), 1197-1205. doi:10.1002/hyp.6690

Zhang, L., Dawes, W., \& Walker, G. (2001). Response of mean annual evapotranspiration to vegetation changes at catchment scale. Water Resources Research, 37(3), 701-708. 


\section{Tables}

Table 1. Drivers of matagouri sap flow, December 6, 2014 to May 6, 2016: Linear mixedeffects model results. The best fit model included soil moisture at both $30 \mathrm{~cm}$ and $60 \mathrm{~cm}$ depth, but these moisture data were strongly correlated and there was little difference between models using both or either as predictors.

\begin{tabular}{|l|l|l|l|l|l|}
\hline \multicolumn{6}{|l|}{ Fixed effects: Sap flow $\sim$ radiation + VPD $+30 \mathrm{~cm}$ soil moisture $+60 \mathrm{~cm}$ soil moisture } \\
\hline $\mathrm{d}$ & Value & Std.Error & DF & t-value & p-value \\
\hline (Intercept) & -0.01166 & 0.00902 & 649 & -1.29233 & 0.1967 \\
\hline $\mathrm{rad}$ & 0.00037 & 0.00006 & 649 & 6.50663 & 0 \\
\hline VPD & 0.00164 & 0.00012 & 649 & 13.12677 & 0 \\
\hline $30 \mathrm{~cm}$ soil moisture & -0.00064 & 0.00022 & 649 & -2.83898 & 0.0047 \\
\hline $60 \mathrm{~cm}$ soil moisture & 0.00139 & 0.00029 & 649 & 4.76357 & 0 \\
\hline
\end{tabular}




\section{Figures}
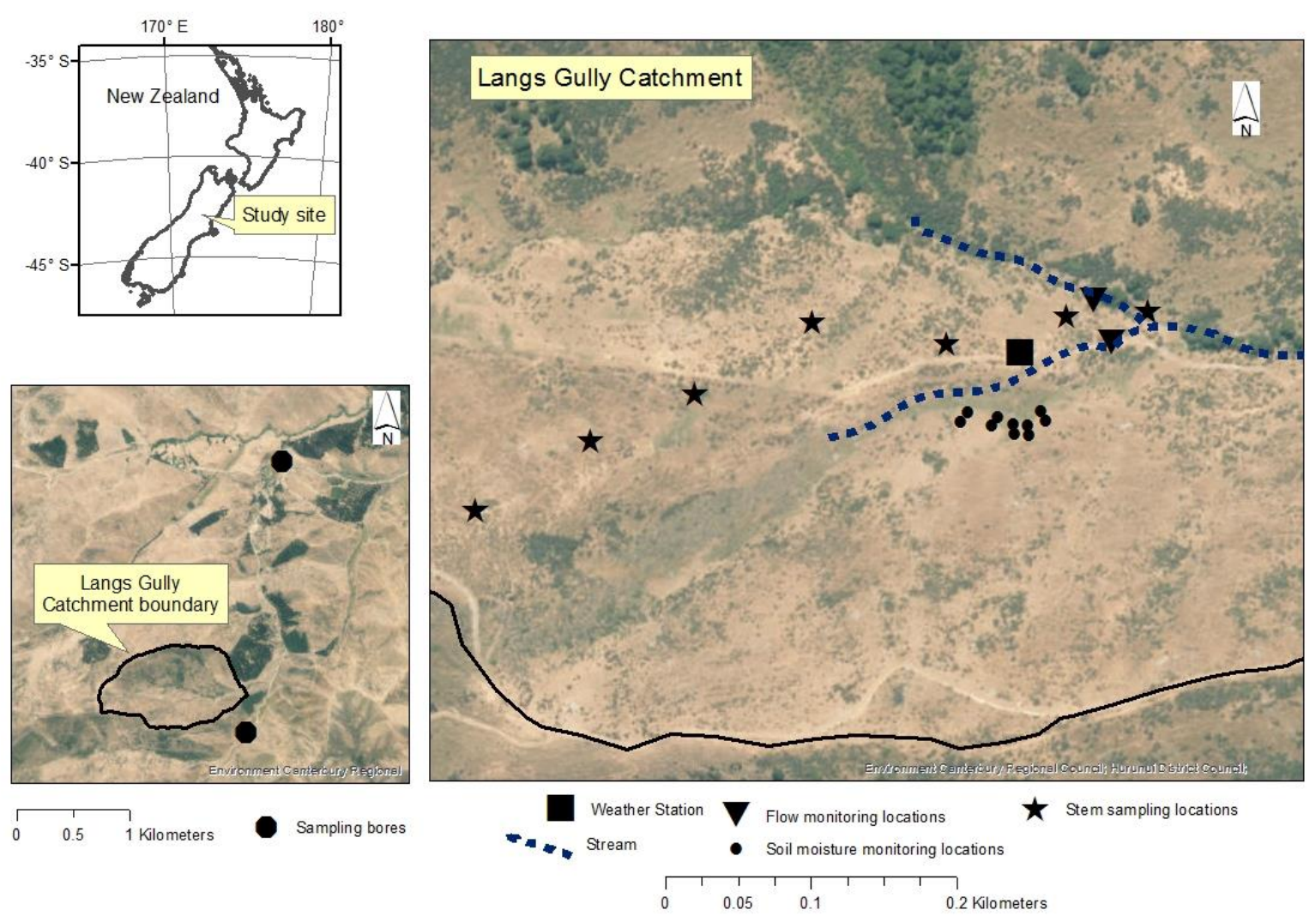

Figure 1. Maps of the study area showing sampling and equipment locations. Soil and stem sampling locations were dispersed from the stream edge (M0) to near the ridgeline (M6), and sapflow sampling was conducted near the weather station, adjacent to site M1. Groundwater was sampled just outside the study catchment. 


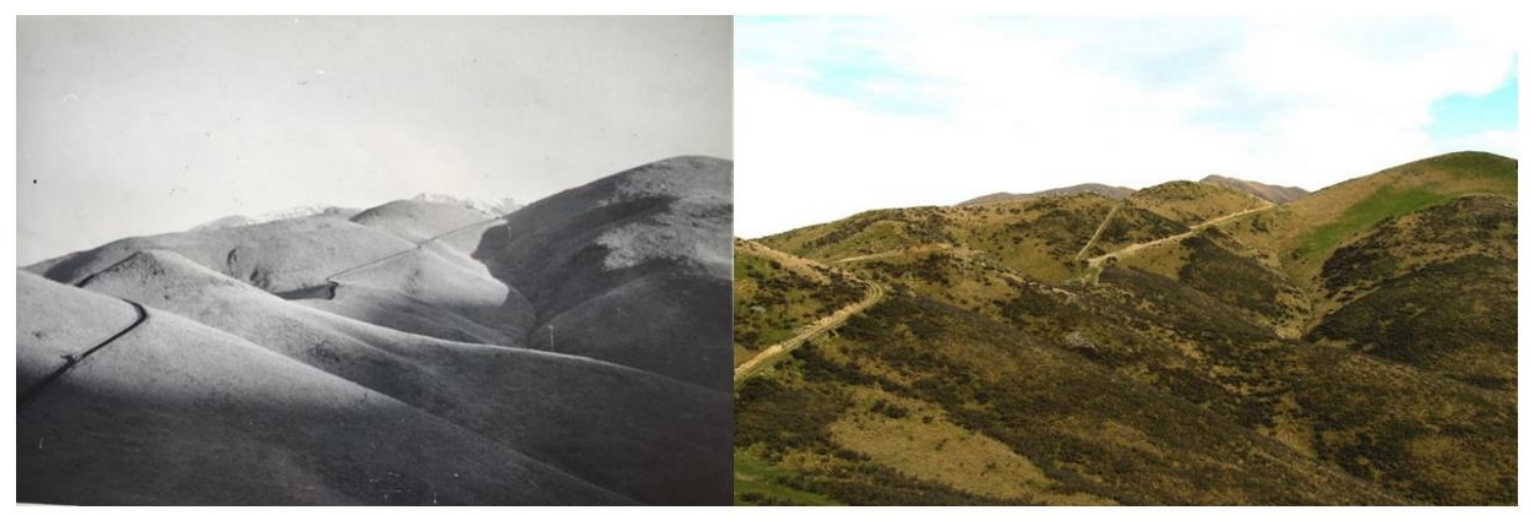

Figure 2. The study site in 1959 (left) and 2004 (right). The dark green shrubs in the later photos are matagouri (Discaria toumatou) which re-grew after burning practices were curtailed in the late 1960 s to reduce erosion. 

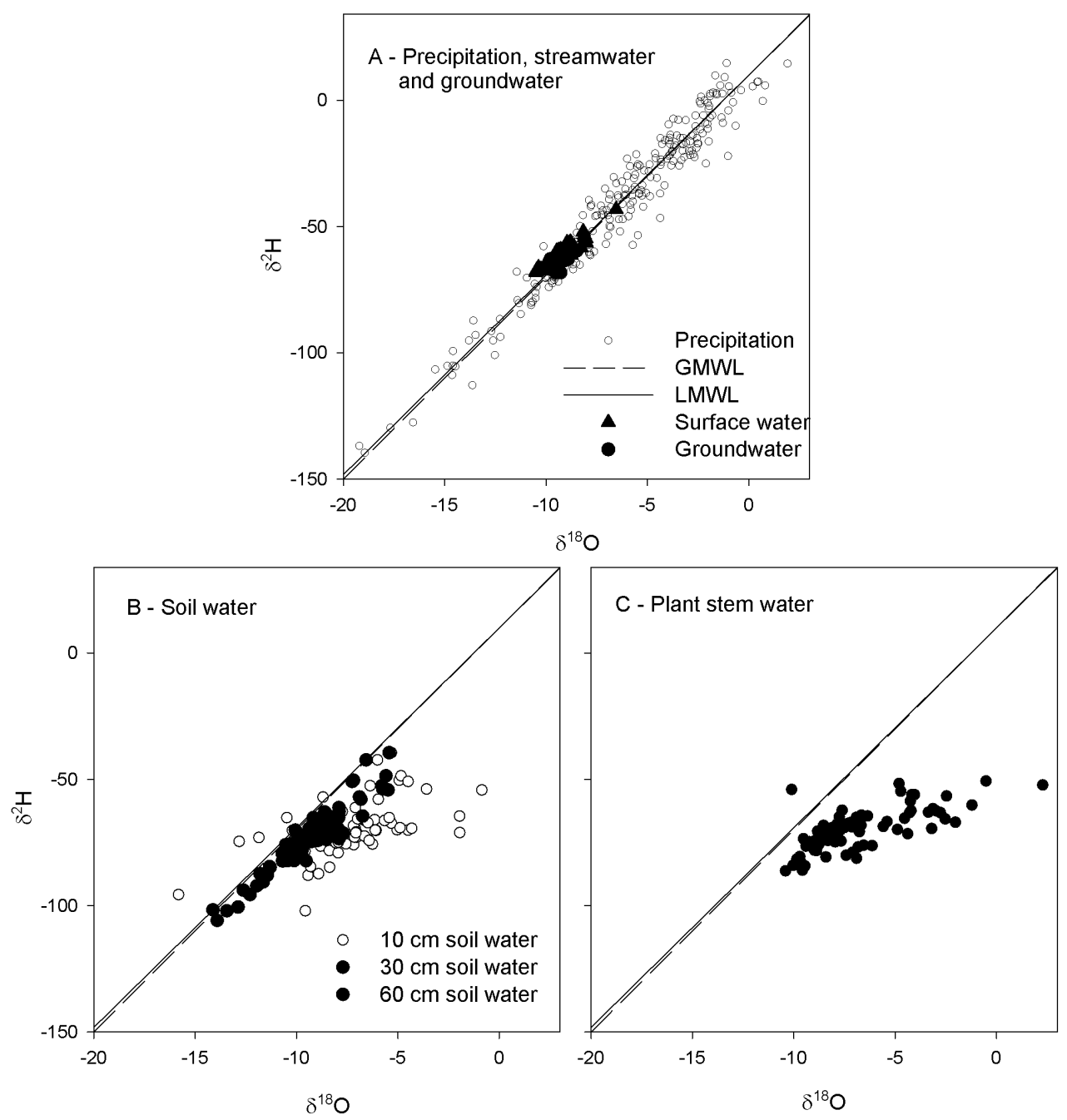

Figure 3. A) $\delta^{18} \mathrm{O}$ and $\delta^{2} \mathrm{H}$ values of groundwater and streamwater (data from Marttila et al. 2017) and B) and C), plant stem water and soil water from within the Lang's Gully catchment, plotted against the local and global meteoric water line (LMWL and GMWL, respectively). Groundwater and streamwater showed close adherence to meteoric water lines, while plant stem and soil water showed substantial deviation, indicating partial evaporation after precipitation. 

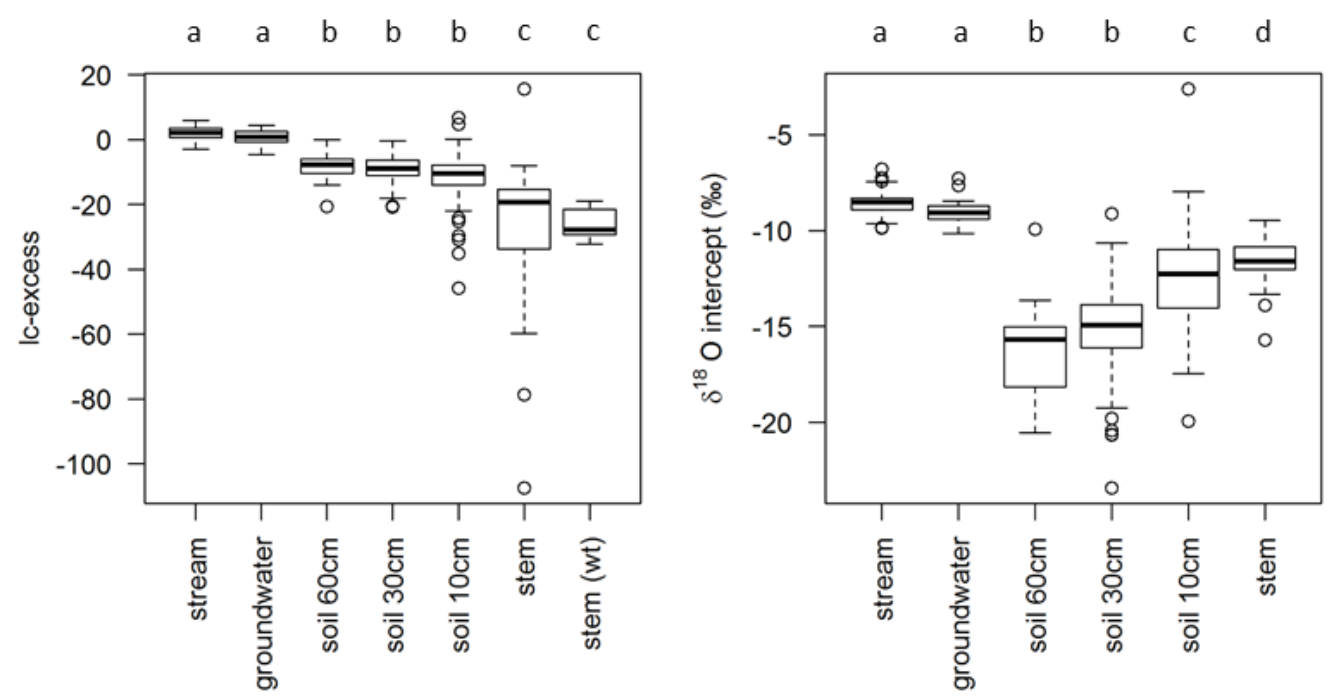

Figure 4. A) Line-conditioned excess (lc-excess) values of streamwater, groundwater, plant stem water, and soil water from within the Lang's Gully catchment. B) Estimates of source precipitation value for groundwater, streamwater, plant stem water, and soil water from within the Lang's Gully catchment. Stem (wt) was calculated for each site by weighting the monthly lc-excess by the proportion of annual sapflow for that month (equation 2). Box plot horizontal lines show median and quartiles, upper bounds of whiskers give maximum and minimum values excluding outliers ( $>1.5$ times the interquartile range). Letters on the top axis of the plots give the results of Games-Howell post hoc tests; water pools that are significantly different at $\alpha<0.05$ are marked with different lower-case letters. 

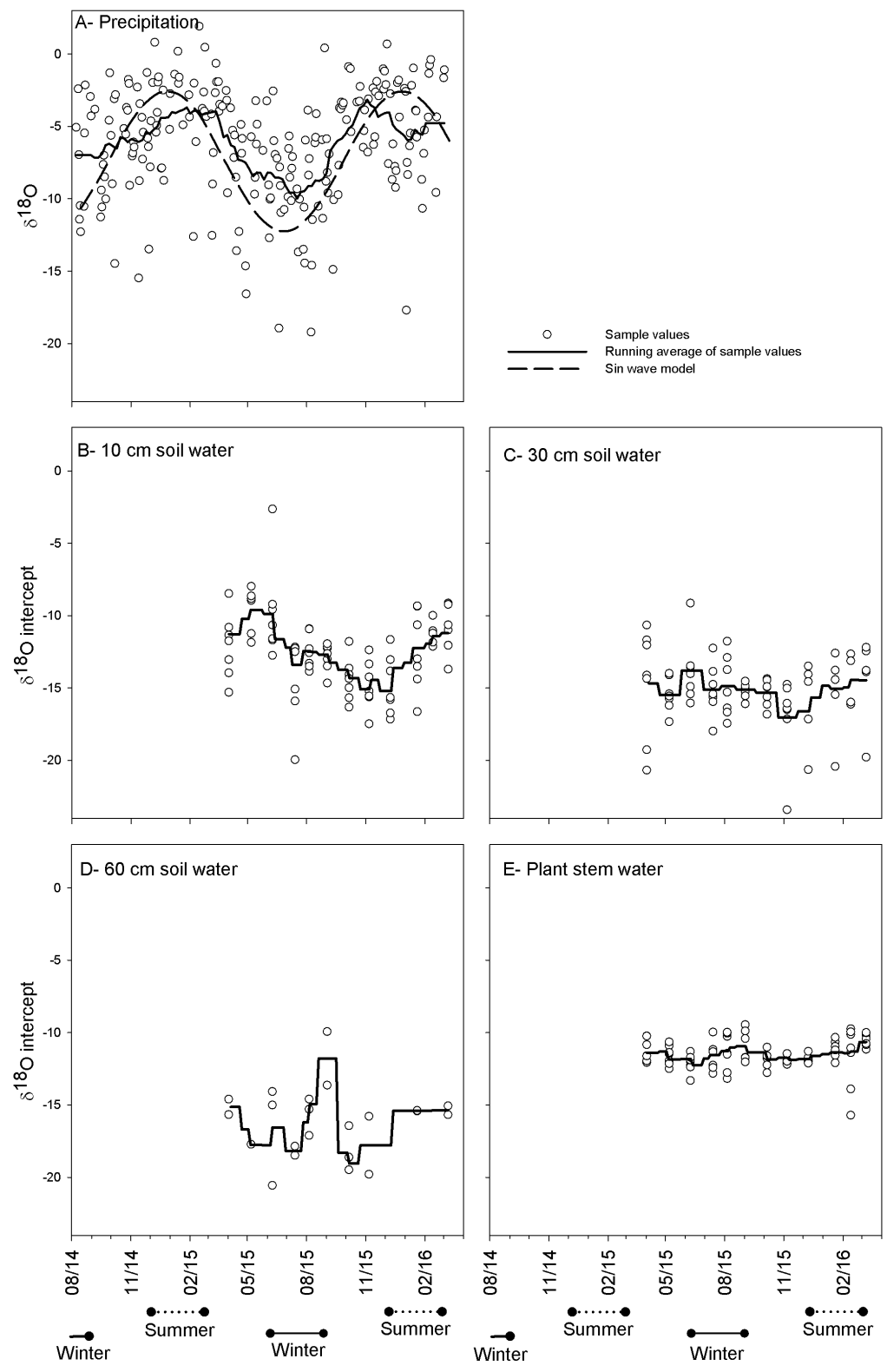

Figure 5. A) Annual patterns of $\delta^{18} \mathrm{O}$ in precipitation (data from Marttila et al. 2017). B-E) Annual patterns of $\delta^{18} \mathrm{O}$-intercepts, indicating precipitation source $\delta^{18} \mathrm{O}$ for soil water and matagouri stem water. Shallower soil water and matagouri stem water showed greater contributions from high- $\delta^{18} \mathrm{O}$ summer rainfall events, while those in deeper soil layers were less variable and derived to a greater extent from isotopically lighter (more negative) winter rainfall. 


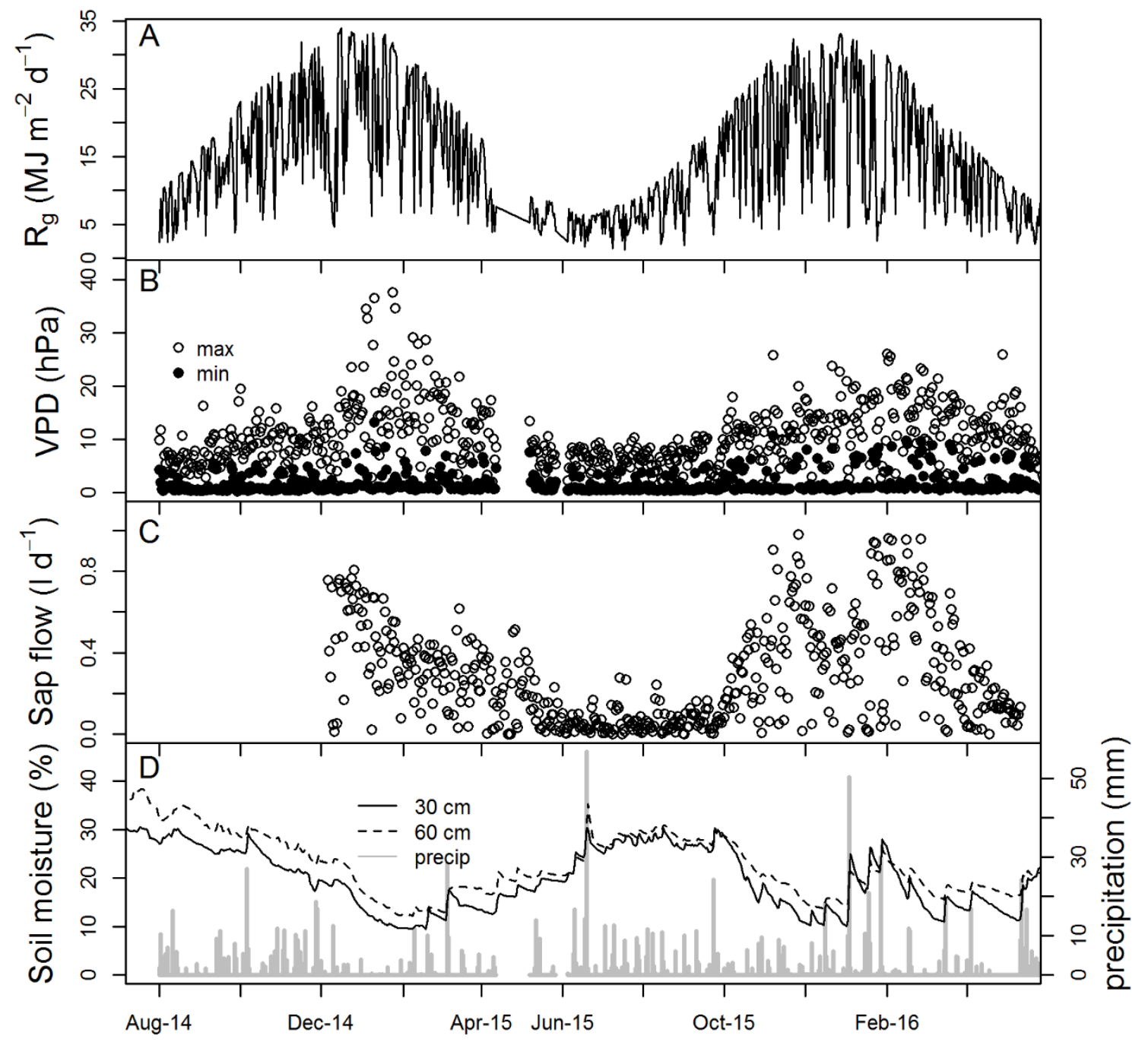

Figure 6. Temporal patterns of: A) Solar radiation, B) vapor pressure deficit, C) average daily sap flow, and D) precipitation and soil moisture from sensor arrays. Sap flow rates for shrubs $(n=8)$ were dependent on shallow soil moisture content, VPD, and radiation. 


\section{Supplementary information:}

Table A1. A) Relationship between stem diameter and bark thickness of matagouri (Discaria toumatou); $\mathrm{n}=21$, stem diameter range $12-81 \mathrm{~mm}$ at $100 \mathrm{~mm}$ above ground level. B) Stem wood properties, derived from a single wood core taken from each of a subset $(n=15)$ of stems measured for bark thickness..

\begin{tabular}{|c|c|c|c|c|}
\hline $\mathbf{A}$ & \multicolumn{4}{|c|}{ Linear regression of bark thickness against stem diameter $(\mathbf{m m})$} \\
\hline $\mathrm{R}$ & $\mathrm{R}^{2}$ & Adj $R^{2}$ & \multicolumn{2}{|c|}{ Standard Error of Estimate } \\
\hline 0.9094 & 0.827 & 0.8179 & \multicolumn{2}{|l|}{0.4459} \\
\hline & Coefficient & Std. Error & $\mathrm{t}$ & $\mathrm{P}$ \\
\hline y0 & 0.9328 & 0.259 & 3.602 & 0.0019 \\
\hline $\mathrm{a}$ & 0.053 & 0.0056 & 9.531 & $<0.0001$ \\
\hline \multirow[t]{2}{*}{ B } & \multicolumn{4}{|c|}{ Mean values for stem wood metrics } \\
\hline & $\begin{array}{l}\text { Density of wet } \\
\text { wood }\left(\mathrm{g} / \mathrm{cm}^{3}\right)\end{array}$ & $\begin{array}{l}\text { Volume fraction } \\
\text { water }\end{array}$ & Volume fraction air & $\begin{array}{l}\text { Volume fraction } \\
\text { wood }\end{array}$ \\
\hline Means & 1.143 & 0.395 & 0.116 & 0.489 \\
\hline $\begin{array}{l}\text { Standard } \\
\text { errors }(n=15)\end{array}$ & 0.010 & 0.009 & 0.009 & 0.004 \\
\hline
\end{tabular}

Table A2. Land-area based transpiration calculations for matagouri (Discaria toumatou) following methods of (Čermák, Kučera, \& Nadezhdina, 2004). Sap flux data for this calculation were collected between 16/01/2016 and 11/05/2016, a period for which sensors in six of the eight sample shrub stems 
delivered constant data. The relationship between stem diameter and mean sap flow is these six stems over this period followed the relationship $\mathrm{y}=0.0001 \mathrm{x}^{2.7277}\left(\mathrm{r}^{2}=0.85\right)$, where $\mathrm{x}$ is stem diameter at $10 \mathrm{~cm}$ above ground level, and $\mathrm{y}$ is sapflow in $1 / \mathrm{hr}$. Stem counts and diameters used for upscaling were collected from within a $7.5 \mathrm{~m}$ radius of the center point of five sites (M1-M5). We note that these data are corrected for wounding according to Green, Clothier, and Jardine (2003), but not calibrated. See Steppe, De Pauw, Doody, and Teskey (2010) for potential implications for upscaling. We note also that these data represent shrubs from a riparian area; while our results suggest use of groundwater in this area was minor, they do not rule out groundwater access. Hence, these sapflow values may not be representative of conditions within the catchment where groundwater was at greater depths.

\begin{tabular}{cccccc}
$\begin{array}{c}\text { Stem } \\
\text { diameter size } \\
\text { class }\end{array}$ & $\begin{array}{c}\text { Average } \\
\text { count } \\
\text { per } \\
\text { hectare } \pm \\
\text { S.E. }(\mathbf{n}=\mathbf{5} \\
\text { plots) }\end{array}$ & $\begin{array}{c}\text { Median } \\
\text { calculated } \\
\text { sapflow for } \\
\text { stems in each } \\
\text { size class } \\
\text { (l/hr) }\end{array}$ & $\begin{array}{c}\text { Total } \\
\text { transpiration } \\
\text { per size class } \\
(\mathbf{l} / \mathbf{h r} / \mathbf{h a})\end{array}$ & $\begin{array}{c}\text { Cumulative } \\
\text { transpiration } \\
(\mathbf{l} / \mathbf{h r} / \mathbf{h a})\end{array}$ & $\begin{array}{c}\text { Cumulative } \\
\text { transpiration } \\
\text { (mm/year) }\end{array}$ \\
\hline$<2 \mathrm{~cm}$ & $685 \pm 198$ & 0.0004 & $0.31 \pm 0.09$ & $0.31 \pm 0.09$ & $0.27 \pm 0.08$ \\
\hline $2-3 \mathrm{~cm}$ & $1705 \pm 530$ & 0.0012 & $2.10 \pm 0.65$ & $2.41 \pm 0.74$ & $2.11 \pm 0.65$ \\
\hline $3-4 \mathrm{~cm}$ & $1316 \pm 409$ & 0.0031 & $4.03 \pm 1.25$ & $6.44 \pm 1.99$ & $5.64 \pm 1.75$ \\
\hline $4-5 \mathrm{~cm}$ & $1030 \pm 298$ & 0.0061 & $6.27 \pm 1.82$ & $12.72 \pm 3.81$ & $11.14 \pm 3.34$ \\
\hline $5-6 \mathrm{~cm}$ & $721 \pm 286$ & 0.0107 & $7.72 \pm 3.06$ & $20.43 \pm 6.87$ & $17.90 \pm 6.02$ \\
\hline $6-7 \mathrm{~cm}$ & $442 \pm 216$ & 0.0167 & $7.38 \pm 3.61$ & $27.81 \pm 10.48$ & $24.36 \pm 9.18$ \\
\hline $7-8 \mathrm{~cm}$ & $211 \pm 74$ & 0.0246 & $5.20 \pm 1.81$ & $33.01 \pm 12.29$ & $28.91 \pm 10.76$ \\
\hline$>8 \mathrm{~cm}$ & $266 \pm 146$ & 0.0553 & $14.72 \pm 8.05$ & $47.72 \pm 20.34$ & $41.81 \pm 17.82$
\end{tabular}


Table A3. Hydraulic conductivity values $\left(\mathrm{K}, \mathrm{m} \mathrm{s}^{-1}\right)$ and $\mathrm{pF}$-curve values for Lang's Gully samples. Hydraulic conductivity varied between $1.3 \cdot 10^{-6}$ and $6.9 \cdot 10^{-6} \mathrm{~m} \mathrm{~s}^{-1}$, typical values for silty loess and clay soils. Soils at the study site have good water retention capacity $(\mathrm{pF})$, especially upper soil layers. At wilting point, volumetric water content (\%) in upper layers was still over $20 \%$, while at field capacity soil contained almost $40 \%$ water. This analysis suggests that local soil can retain substantial soil moisture during dry periods and that vegetation may utilize this soil water.

\begin{tabular}{|c|c|c|c|c|c|c|c|c|c|c|c|c|c|c|}
\hline \multirow[b]{4}{*}{ Site } & \multirow[b]{4}{*}{$\begin{array}{l}\text { Depth } \\
(\mathrm{cm})\end{array}$} & \multirow[b]{3}{*}{$\begin{array}{l}\text { Hydraulic } \\
\text { conductivity, }\end{array}$} & \multirow{2}{*}{$\begin{array}{l}\text { bar } \\
\text { pF-number }\end{array}$} & \multirow[t]{2}{*}{0} & \multirow{2}{*}{$\begin{array}{l}0.012 \\
1.08\end{array}$} & \multirow{2}{*}{$\begin{array}{l}0.025 \\
1.40\end{array}$} & \multirow{2}{*}{$\begin{array}{l}0.05 \\
1.70\end{array}$} & \multirow{2}{*}{$\begin{array}{l}0.1 \\
2.00\end{array}$} & \multirow{2}{*}{$\begin{array}{l}0.25 \\
2.40\end{array}$} & \multirow{2}{*}{$\begin{array}{l}0.5 \\
2.70\end{array}$} & \multirow{2}{*}{$\begin{array}{l}1 \\
3.00\end{array}$} & \multirow{2}{*}{$\begin{array}{l}2.5 \\
3.40\end{array}$} & \multirow{2}{*}{$\begin{array}{l}5 \\
3.70\end{array}$} & \multirow{2}{*}{$\begin{array}{l}10 \\
4.00\end{array}$} \\
\hline & & & & & & & & & & & & & & \\
\hline & & & & & & & & & & & & & & \\
\hline & & $\begin{array}{l}\mathrm{K}, \\
(\mathrm{m} / \mathrm{s})\end{array} \quad 20^{\circ} \mathrm{C}$ & $\mathrm{kPa}$ & 0 & 1.2 & 2.5 & 5 & 10 & 25 & 50 & 100 & 250 & 500 & 1000 \\
\hline M0 & $0-5$ & $4.00 \mathrm{E}-06$ & Vol $\%$ water & 55.28 & 47.08 & 41.93 & 36.95 & 32.19 & 28.99 & 26.74 & 24.38 & 22.70 & 20.90 & 17.97 \\
\hline M0 & $30-35$ & $1.50 \mathrm{E}-06$ & Vol $\%$ water & 39.09 & 30.09 & 24.84 & 21.49 & 19.27 & 16.85 & 15.88 & 14.64 & 13.46 & 12.14 & 9.21 \\
\hline M0 & $60-65$ & $2.30 \mathrm{E}-06$ & Vol \% water & 33.24 & 29.13 & 28.19 & 27.21 & 26.60 & 25.55 & 24.90 & 23.38 & 21.73 & 18.73 & 15.80 \\
\hline Station & $0-5$ & $1.80 \mathrm{E}-06$ & Vol \% water & 59.70 & 52.99 & 47.05 & 43.68 & 40.17 & 35.94 & 33.87 & 31.98 & 29.41 & 27.06 & 24.13 \\
\hline Station & $30-35$ & $6.00 \mathrm{E}-07$ & Vol \% water & 43.59 & 39.29 & 36.63 & 33.22 & 31.15 & 28.24 & 26.68 & 24.50 & 22.48 & 19.44 & 16.51 \\
\hline Station & $60-65$ & $1.30 \mathrm{E}-06$ & Vol \% water & 38.58 & 38.43 & 36.03 & 33.39 & 31.10 & 27.72 & 26.07 & 23.83 & 21.72 & 19.83 & 16.90 \\
\hline North face & $0-5$ & $2.60 \mathrm{E}-06$ & Vol $\%$ water & 56.72 & 52.57 & 49.05 & 42.72 & 38.34 & 34.84 & 33.18 & 32.04 & 30.78 & 28.93 & 25.99 \\
\hline North face & $30-35$ & $2.80 \mathrm{E}-07$ & Vol \% water & 40.54 & 34.11 & 31.54 & 23.49 & 20.19 & 17.17 & 15.38 & 13.54 & 12.07 & 9.90 & 6.96 \\
\hline North face & $60-65$ & $6.90 \mathrm{E}-08$ & Vol \% water & 38.23 & 35.52 & 32.62 & 29.56 & 27.50 & 25.11 & 23.79 & 22.09 & 19.87 & 17.88 & 14.94 \\
\hline M2 & $0-5$ & $1.80 \mathrm{E}-06$ & Vol \% water & 57.90 & 54.07 & 47.73 & 41.33 & 36.71 & 32.51 & 29.80 & 27.83 & 26.19 & 23.42 & 20.48 \\
\hline M2 & $30-35$ & $1.80 \mathrm{E}-07$ & Vol \% water & 45.12 & 40.52 & 35.92 & 31.83 & 27.90 & 23.72 & 22.11 & 19.73 & 17.68 & 15.30 & 12.36 \\
\hline M2 & $60-65$ & $1.60 \mathrm{E}-06$ & Vol $\%$ water & 42.69 & 40.04 & 36.11 & 32.45 & 29.95 & 26.31 & 24.35 & 22.42 & 20.07 & 17.08 & 14.14 \\
\hline
\end{tabular}



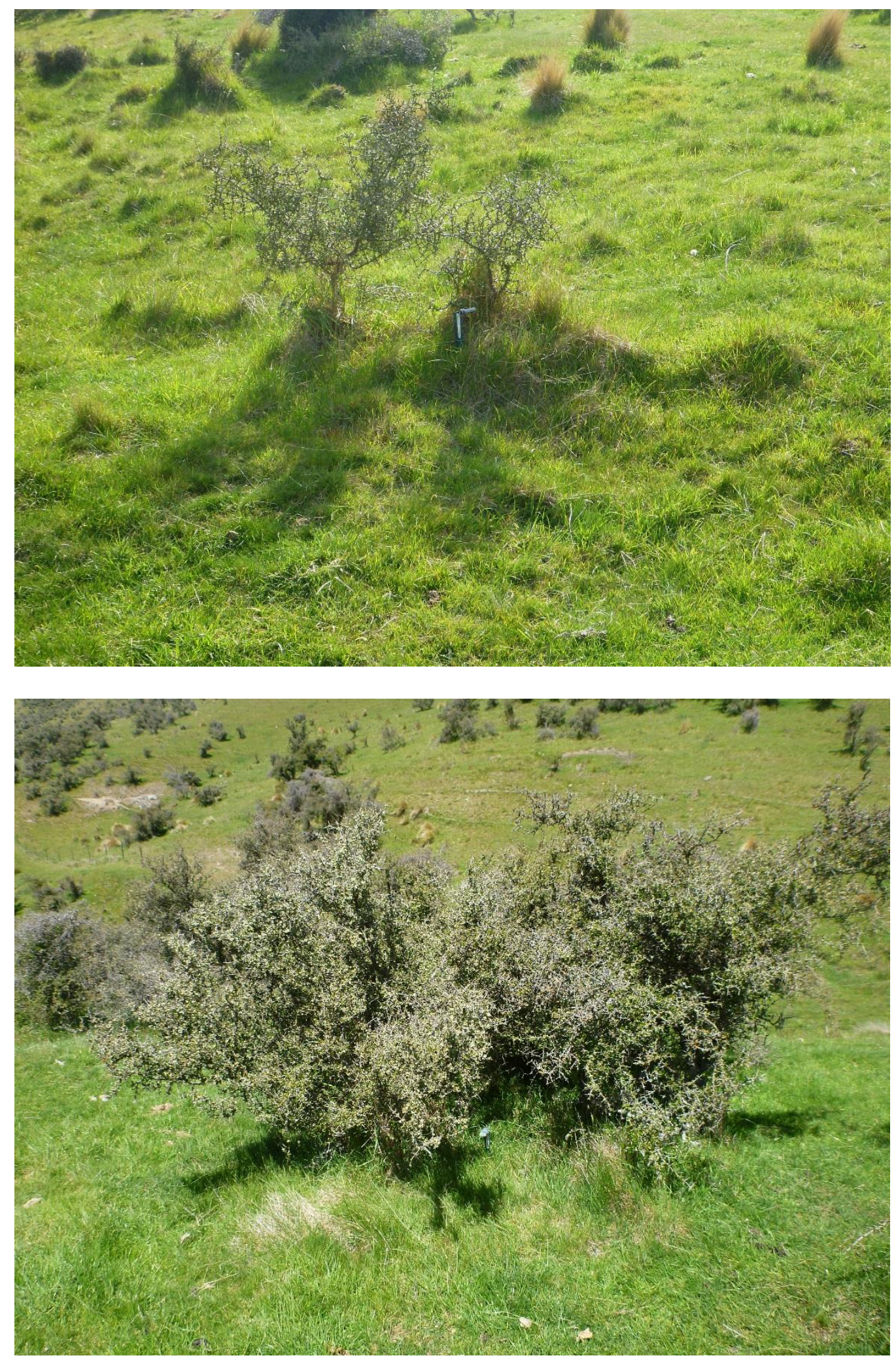
Figure A1. (Top) Small matagouri (Discaria toumatou) plant of around 2-3 cm basal diameter (ca. 40$50 \mathrm{~cm}$ height) and (bottom) group of several larger matagouri plants of 8-12 $\mathrm{cm}$ basal diameter (ca. $150 \mathrm{~cm}$ height). 


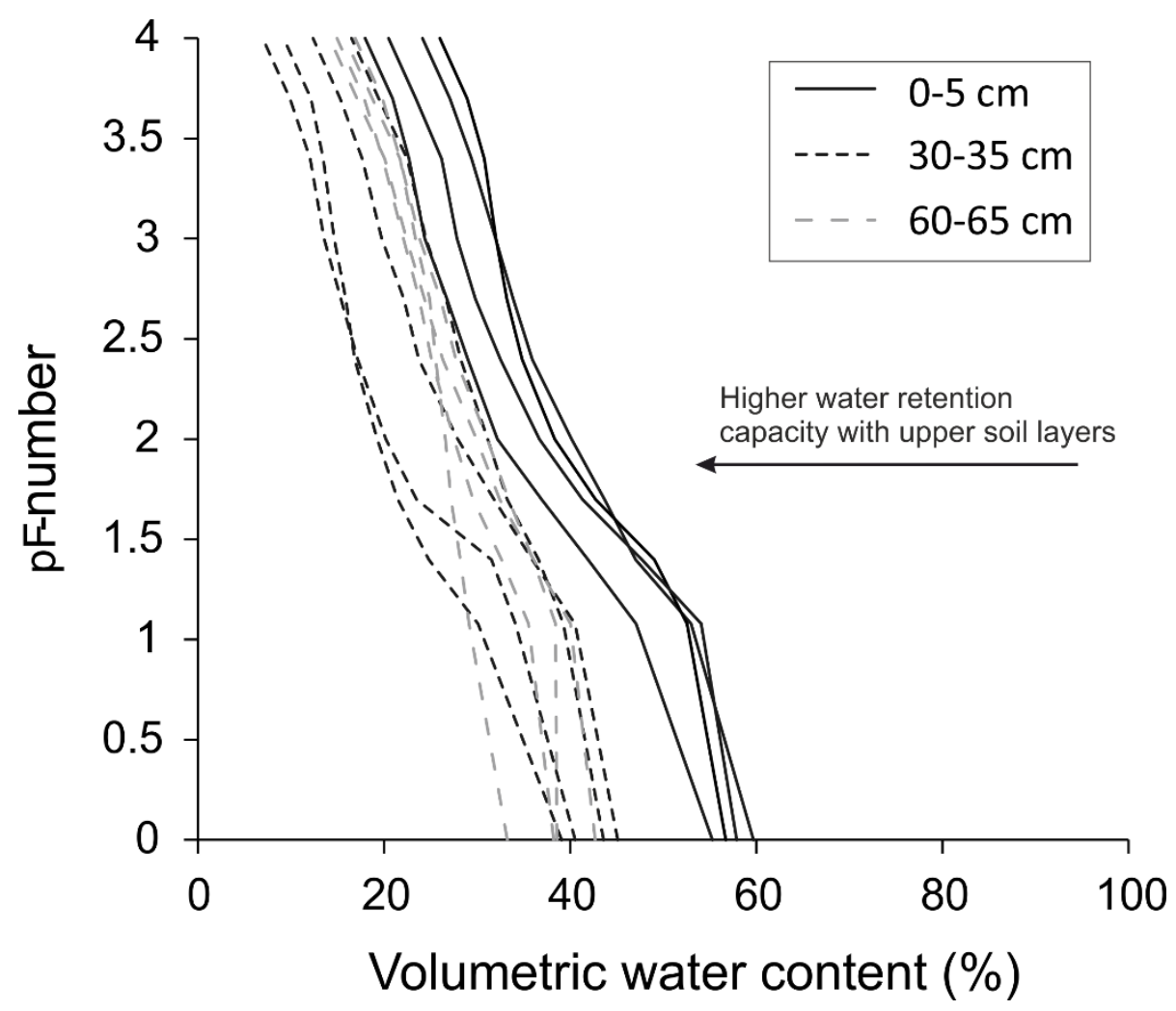

Figure A2. Water retention curves $(\mathrm{pF})$ for soil samples classified according to soil depth. This gives the relation between soil moisture suction and soil moisture content. Upper soil layers had higher retention capacity at all suction values. 

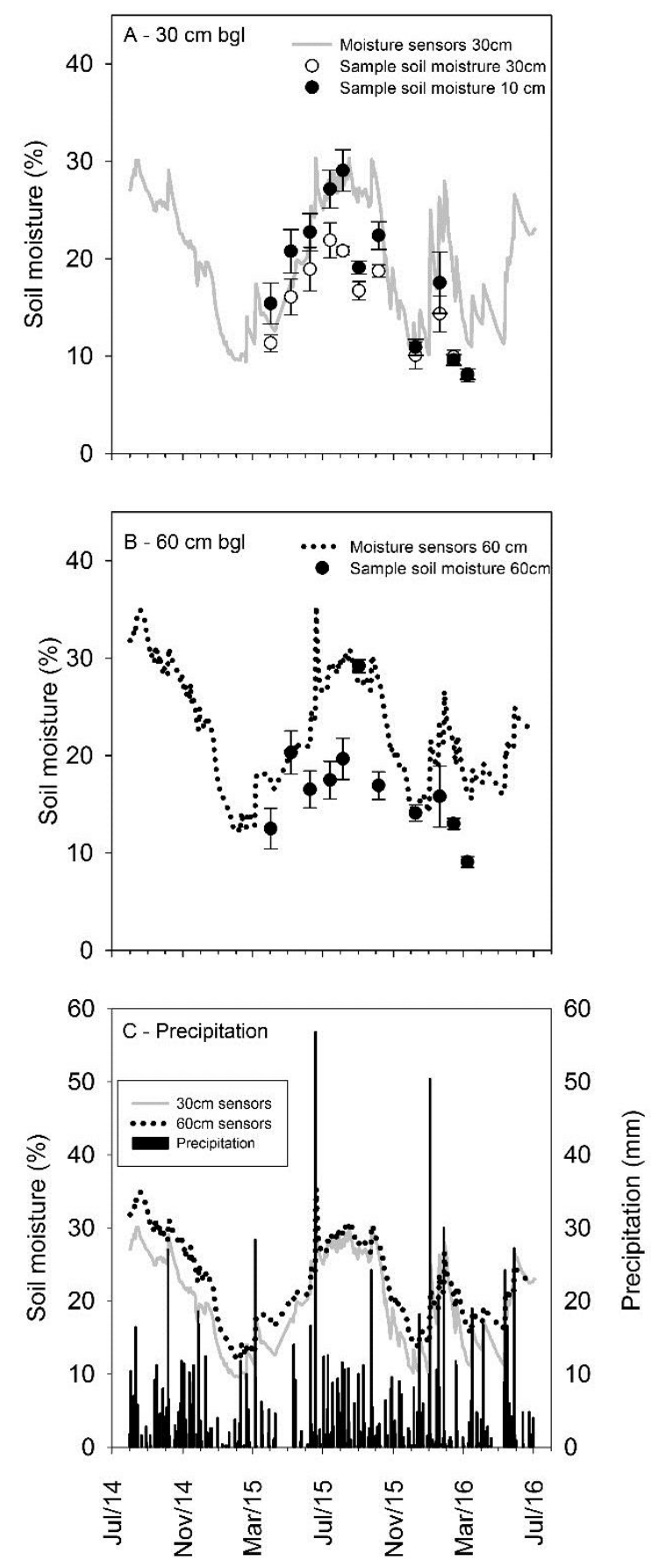

Figure A3. A and B: Temporal patterns of soil moisture in isotope samples, relative to soil moisture sensor data. Soil moisture in isotope samples generally plotted below the line of the soil moisture sensor array but show a similar pattern through time. This indicates drier soil condition on much of the hillslope above the soil moisture array. C: Temporal patterns of soil moisture sensor data relative to precipitation at the weather station within the catchment. 
Čermák, J., Kučera, J., \& Nadezhdina, N. (2004). Sap flow measurements with some thermodynamic methods, flow integration within trees and scaling up from sample trees to entire forest stands. Trees, 18(5), 529-546.

Green, S. R., Clothier, B. E., \& Jardine, B. (2003). Theory and practical application of heat pulse to measure sap flow. Agronomy Journal, 95(6), 1371-1379.

Steppe, K., De Pauw, D. J., Doody, T. M., \& Teskey, R. O. (2010). A comparison of sap flux density using thermal dissipation, heat pulse velocity and heat field deformation methods.

Agricultural and Forest Meteorology, 150(7), 1046-1056. 